\title{
Stability indicating RP-LC-PDA method for the quantitative analysis of saxagliptin in pharmaceutical dosage form
}

\author{
Laís Engroff Scheeren ${ }^{1}$, Ana Isa Pedroso Marcolinoํ, Andréa Inês Horn Adams ${ }^{1,2}$, Clarice Madalena \\ Bueno Rolim ${ }^{1,2, *}$
}

${ }^{1}$ Graduate Programme in Pharmaceutical Sciences, Federal University of Santa Maria, RS, Brazil, ${ }^{2}$ Department of Industrial Pharmacy, Federal University of Santa Maria, Santa Maria, RS, Brazil

\begin{abstract}
Saxagliptin is a potent and selective inhibitor of the enzyme dipeptidyl peptidase 4. It is effective in the treatment of type 2 diabetes mellitus because it stimulates the pancreas to produce insulin. In the present study, a liquid chromatography method was developed and validated to quantify the drug in tablets. This method was based on the isocratic elution of saxagliptin, using a mobile phase consisting of $0.1 \%$ phosphoric acid at pH $3.0-$ methanol $(70: 30, \mathrm{v} / \mathrm{v})$ at a flow rate of $1 \mathrm{~mL} \cdot \mathrm{min}^{-1}$ with UV detection at $225 \mathrm{~nm}$. The chromatographic separation was achieved in 8 minutes on a Waters XBridge C18 column $(250 \mathrm{~mm} \times 4.6 \mathrm{~mm}, 5 \mu \mathrm{m})$ maintained at ambient temperature. The proposed method proved to be specific and robust for the quality control of saxagliptin in pharmaceutical dosage forms, showing good linearity in the range of $15.0-100.0 \mu \mathrm{g} \cdot \mathrm{mL}^{-1}(\mathrm{r}>0.999)$, precision $(\mathrm{RSD}<1.49 \%)$ and accuracy values between 99.42 and $101.59 \%$. The method was found to be stability indicating and was successfully applied for the analysis of saxagliptin in tablets in a routine quality control laboratory.
\end{abstract}

Uniterms: Saxagliptin/tablets/quality control. High Performance Liquid Chromatography/quantitative analysis.

A saxagliptina é uma inibidora potente e seletiva da enzima dipeptidil peptidase 4. É efetiva no tratamento do Diabete mellitus tipo 2, pois estimula a produção de insulina pelo pâncreas. No presente estudo, desenvolveu-se e validou-se método por cromatografia líquida de alta eficiência para quantificar o fármaco em comprimidos. O método foi baseado em eluição isocrática, utilizando fase móvel constituída por ácido fosfórico 0,1\% pH 3,0-metanol (70:30, v/v), fluxo de 1,0 mL.min ${ }^{-1}$, com detecção UV em $225 \mathrm{~nm}$. A separação cromatográfica foi alcançada em 8 minutos em coluna Waters XBridge C18 (250 mm x 4,6 mm, $5 \mu \mathrm{m})$ mantida à temperatura ambiente. $\mathrm{O}$ método proposto mostrou-se específico e robusto para o controle de qualidade de saxagliptina em comprimidos, sendo linear na faixa de concentração de 15,0-100,0 $\mu \mathrm{g} \cdot \mathrm{mL}^{-1}(\mathrm{r}>0,999)$, preciso $(\mathrm{RSD}<1,49 \%$ ) e exato, com resultados entre 99,42 e 101,59\%. O método mostrou-se indicativo de estabilidade e foi aplicado com sucesso no controle de qualidade de saxagliptina em comprimidos.

Unitermos: Saxagliptina/comprimidos/controle de qualidade. Cromatografia líquida de alta eficiência/ análise quantitativa.

\section{INTRODUCTION}

Saxagliptin (SAX, BMS-477118; Figure 1), is a potent, selective, long-acting and reversible inhibitor of the enzyme dipeptidyl peptidase 4 (DPP 4) used for

\footnotetext{
*Correspondence: C. M. B. Rolim. Programa de Pós-Graduação em Ciências Farmacêuticas. Universidade Federal de Santa Maria. Avenida Roraima, ${ }^{\circ}$ 1000 - Cidade Universitária, Bairro Camobi - 97105-900 - Santa Maria - RS, Brasil. E-mail: clarice.rolim@gmail.com
}

the treatment of type 2 diabetes mellitus. Inhibition of this enzyme results in increased concentrations of the glucagon-like peptide 1 (GPL-1) and other endogenous incretins and consequently increases the stimulation of insulin release from the pancreas (Augeri et al., 2005).

Saxagliptin belongs to a group of anti-diabetic drugs, the DPP 4 inhibitors, along with sitagliptin and vildagliptin, but the former appears to be more potent since it is effective in the $2.5-10.0 \mathrm{mg}$ range once a 


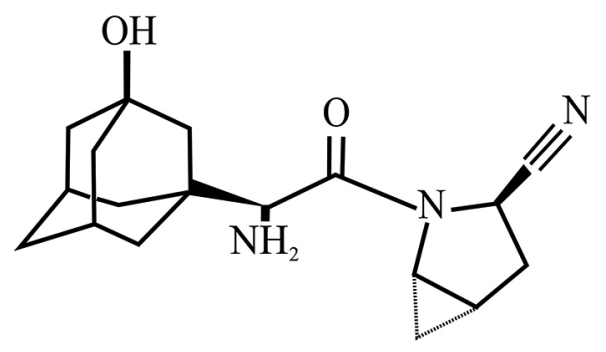

FIGURE 1 - Chemical structure of saxagliptin.

day compared with the therapeutic dose of $100 \mathrm{mg}$ of sitagliptin (Deacon; Holst, 2009). Furthermore, saxagliptin can be used as monotherapy or combined with metformin, glyburide or thiazolidinedione (Karyekar et al., 2011).

In 2009, saxagliptin was approved by the European Medicines Agency (EMA) for the treatment of type 2 diabetes mellitus (EMA, 2009, 2013). Since then, bioanalytical HPLC methods have been reported to quantify saxagliptin and its major pharmacologically active metabolite, 5-hydroxy saxagliptin, in human plasma, which were applied to pharmacokinetic studies (Patel et al., 2010; Xu et al., 2012). Gao et al. (2012) developed and validated a method by UPLC-MS/MS for quantification of this pharmaceutical substance in plasma. The applicability of the method was demonstrated in a pharmacokinetic study in healthy rats. Nevertheless, the previously reported methods do not deal with the determination of the drug in pharmaceutical dosage form and are not suitable for quality control routine analysis. For pharmaceutical formulation, Kalaichelvi and Jayachandran (2011) developed a UV spectrophotometric method to determine saxaliptin in tablets. However, due to limitation of specificity, it could not be applied to the analysis of stability samples in the pharmaceutical industry, where a stability indicating method is required. Moreover, no official method has been described in the literature for the determination of saxagliptin in pharmaceutical dosage form by liquid chromatography. Therefore, the purpose of this study was to develop and validate a stability indicating reversed-phase liquid chromatography method with UV detection for the quantitative analysis of saxagliptin in pharmaceutical formulation.

\section{MATERIAL AND METHODS}

\section{Chemicals}

Saxagliptin reference substance was obtained from Ontario Chemicals (Ontario, Canada) and was certified to be $98.0 \%$ pure. Tablets containing $5 \mathrm{mg}$ of saxagliptin (Onglyza $^{\mathrm{TM}}$, Bristol-Myers Squibb, New York, NY,
USA) were obtained from commercial sources. Methanol (HPLC grade) was obtained from Tedia (Fairfield, USA) and phosphoric acid from Vetec (Rio de Janeiro, Brazil). Ultrapure water was obtained from Mega Purity System (Canada) water purification unit.

\section{Instrumentation and analytical conditions}

A Shimadzu LC system (Shimadzu, Kyoto, Japan) was used equipped with an LC-20AT pump, a SPD-M20A photodiode array (PDA) detector, a CBM-20A system controller, a DGU-20A5 degasser and a Rheodine ${ }^{\circledR}$ (Rohnert Park, CA, USA) injector model 7725i. The detector was set at $225 \mathrm{~nm}$ and peak areas were integrated automatically by computer using an LC Solution software program (version 1.24 SP1).

The chromatographic system used a Waters XBridge C18 (250 mm x $4.6 \mathrm{~mm}, 5 \mu \mathrm{m})$ column at ambient temperature. Separation was achieved using a mobile phase consisting of $0.1 \%$ phosphoric acid at $\mathrm{pH} 3.0$-methanol $(70: 30, \mathrm{v} / \mathrm{v})$ at a flow rate of $1.0 \mathrm{~mL} \cdot \mathrm{min}^{-1}$ within a runtime of 10 minutes. The injection volume was $20 \mu \mathrm{L}$.

\section{Saxagliptin reference solution}

The reference stock solution of saxagliptin was prepared by dissolving an accurately weighed $10 \mathrm{mg}$ of reference substance in $20 \mathrm{~mL}$ of methanol acidified medium with $0.4 \mathrm{~mL}$ of $0.1 \%$ phosphoric acid at $\mathrm{pH} 3.0$. This stock solution was stored at $2-8^{\circ} \mathrm{C}$. Further dilutions were made with water until the final concentration of $50.0 \mu \mathrm{g} . \mathrm{mL}^{-1}$ for injection.

\section{Preparation of tablet sample solution}

For the preparation of the sample solution, tablets containing $5 \mathrm{mg}$ of saxagliptin were accurately weighed and crushed. An appropriate amount of the tablet powder (equivalent to $2.5 \mathrm{mg}$ of saxagliptin) was weighed and transferred into a $25 \mathrm{~mL}$ volumetric flask with $15 \mathrm{~mL}$ of methanol and $0.1 \mathrm{~mL}$ of $0.1 \%$ phosphoric acid at $\mathrm{pH} 3.0$. The sample was sonicated for 10 minutes and the flask volume was completed with methanol. Other dilutions were made after centrifugation, with water to reach a test concentration of $50.0 \mu \mathrm{g} . \mathrm{mL}^{-1}$ saxagliptin. The solutions were then filtered through a $0.45 \mu \mathrm{m}$ membrane filter (Sartorius Stedim Biotech, Germany).

\section{Validation of the method}

The method was validated using tablet samples of 
saxagliptin by determining the following parameters: specificity, linearity, precision, accuracy and robustness, according to ICH guidelines (ICH, 2005).

\section{Specificity}

Forced degradation studies were performed by dissolving $10 \mathrm{mg}$ of saxagliptin in $50 \mathrm{~mL}$ of methanol and later $5 \mathrm{~mL}$ of this sample (equivalent to $1000 \mu \mathrm{g}$ of saxagliptin) was separately diluted with $5 \mathrm{~mL}$ of $1 \mathrm{~mol} . \mathrm{L}^{-1}$ hydrochloric acid and $5 \mathrm{~mL}$ of $0.1 \mathrm{~mol} . \mathrm{L}^{-1}$ sodium hydroxide. The studies under acid and alkaline conditions were carried out at $60^{\circ} \mathrm{C}$ for 2 hours and at ambient temperature for 10 minutes, respectively, neutralized and then diluted with water in a $20 \mathrm{~mL}$ volumetric flask to achieve a concentration of $50.0 \mu \mathrm{g} \cdot \mathrm{mL}^{-1}$. The oxidative condition was obtained by contacting the sample diluted in methanol at $1000 \mu \mathrm{g} \cdot \mathrm{mL}^{-1}$ saxagliptin with $5 \mathrm{~mL}$ of $30 \%$ hydrogen peroxide, at ambient temperature. After 24 hours, protected from light, the sample was diluted with water to a concentration of $50.0 \mu \mathrm{g} \cdot \mathrm{mL}^{-1}$. Finally, for photodegradation, the amount of the tablet powder was weighed and transferred into a $10 \mathrm{~mL}$ volumetric flask with methanol, from which $1 \mathrm{~mL}$ was removed and exposed in a photostability chamber to $254 \mathrm{~nm}$ for 3 hours and 30 minutes. After exposure, the volume was transferred again to a $10 \mathrm{~mL}$ volumetric flask for concentration $50.0 \mu \mathrm{g} \cdot \mathrm{mL}^{-1}$.

\section{Linearity}

Linearity was determined by constructing three analytical curves, each one with five reference concentrations of saxagliptin in the 15.0-100.0 $\mu \mathrm{g} . \mathrm{mL}^{-1}$ range prepared by diluting an appropriate quantity of reference stock solution with water. Each concentration was injected in triplicate.

\section{Precision}

The precision of the analytical method is evaluated by repeatability (intra-day precision) and intermediate precision (inter-day precision) in the sample solutions. Repeatability was calculated by assaying six samples with a concentration of $50.0 \mu \mathrm{g} . \mathrm{mL}^{-1}$, prepared according to the preparation of the sample solution, all on the same day and under the same experimental conditions. The intermediate precision was achieved from results obtained on three different days (six samples on the first day and three samples on the second and third days) and by another analyst in the same laboratory. The test was determined by calculating relative standard deviation (RSD).

\section{Accuracy}

Accuracy was assessed by determining the ability of the method to recover three different concentrations (corresponding to 80,100 and $120 \%$ of the nominal analytical concentration) by the addition of known amounts $\left(20.0,30.0\right.$ and $\left.40.0 \mu \mathrm{g} . \mathrm{mL}^{-1}\right)$ of the reference solution to the sample solution.

\section{Robustness}

The robustness of the method was evaluated by assaying the test solutions after slight changes in the analytical method. The factors chosen for this study were the composition of the mobile phase (phosphoric acid - methanol, $75: 25$ and $65: 35, \mathrm{v} / \mathrm{v}), \mathrm{pH}$ of phosphoric acid (2.5 and 3.5) and flow rate (0.8 and $\left.1.2 \mathrm{~mL} \cdot \mathrm{min}^{-1}\right)$. The objective was to analyse any impact of each changed condition on method reliability for the routine quality control analysis.

\section{RESULTS AND DISCUSSION}

During the process of method development, several trials were performed testing different columns, different $\mathrm{pH}$ values and different proportion of the mobile phase. A good peak shape was observed when a Waters XBridge C18 (250 mm x $4.6 \mathrm{~mm}, 5 \mu \mathrm{m})$ column was used, which showed efficiency. A mixture of $0.1 \%$ phosphoric acid at $\mathrm{pH}$ 3.0-methanol $(70: 30, \mathrm{v} / \mathrm{v})$ was adopted because saxagliptin is very soluble at low pH (EMA, 2009, 2013). These chromatographic conditions were optimized to separate any degradation products from the saxagliptin peak.

\section{Method validation}

\section{Specificity}

The forced degradation was performed to show that the developed method is able to separate the active from possible degradation products. Degradation was performed under basic, acid, oxidative and light exposure. When submitted to basic condition, the chromatogram showed three possible degradation products close to 3.5 minutes, 5 minutes and 6.5 minutes, while the saxagliptin content decreased about $11.1 \%$. Under acid condition, was found $13.52 \%$ reduction in peak area and no additional peaks were detected. The oxidative condition produced two new peaks close to 5 minutes and the saxagliptin content decreased about $38 \%$. When the samples were exposed to UVC radiation, no degradation peaks were detected and the recovery content was around $61 \%$ 



FIGURE 2 - Chromatograms of saxagliptin (SAX; $50.0 \mu \mathrm{g} \cdot \mathrm{mL}^{-1}$ ): SAX after exposure UVC light (A); SAX after acid hydrolysis (B); SAX after oxidation (C) and SAX after basic hydrolysis (D).

(Figure 2). The placebo was prepared and injected in order to compare it with the tablet sample (Figure 3 ). The studies with the PDA detector showed that the degradation products produced as a result of stress did not interfere in the detection of saxagliptin, with purity peak values greater than 0.9999 and demonstrating the ability to separate the drug from their degradation products. Therefore, it may be employed for analysis of stability samples of saxagliptin, even though the characterization of degradation products was not carried out.

\section{Linearity}

Five reference solutions were prepared containing 15.0, 25.0, 50.0, 75.0 and $100.0 \mu \mathrm{g} . \mathrm{mL}^{-1}$ saxagliptin, corresponding to $30,50,100,150$ and $200 \%$ of the test concentration, respectively. Three curves were constructed by plotting the solution concentration against the peak area. Results are shown in Table I. The validity of the assay was verified by analysis of variance, which showed that there were linear regression and no deviation from linearity $(p<0.05)$.

\section{Precision}

Precision was estimated by repeatability and intermediate precision. The repeatability was assessed by analysing a solution of $50.0 \mu \mathrm{g} \cdot \mathrm{mL}^{-1}$ saxagliptin $(n=6)$ on the same day and under the same conditions. The intermediate precision $(n=12)$ was obtained by another analyst in different day. The RSD values are shown in Table II.

\section{Accuracy}

The accuracy of the RP-LC method was achieved by calculating percentage recovery of the added saxagliptin reference solution. The mean accuracy was $100.72 \%$ with an RSD of $0.37 \%$. These values demonstrated that the method is accurate within the desired range (Table III). 


\section{Robustness}

In all deliberately varied chromatographic conditions, the determination of the drug in the pharmaceutical



FIGURE 3 - Chromatogram of SAX obtained from the injection of SAX reference solution $50.0 \mu \mathrm{g} \cdot \mathrm{mL}^{-1}$ (a), tablet solution 50.0 $\mu \mathrm{g} \cdot \mathrm{mL}^{-1}$ (b) and placebo solution (c). The absorption spectrum of SAX is shown in (d).

TABLE I - Linearity of saxagliptin

\begin{tabular}{lc}
\hline Parameter & Result \\
\hline Linearity range & $15.0-100.0 \mu \mathrm{g} \cdot \mathrm{mL}^{-1}$ \\
Slope & 15159 \\
Intercept & 28514 \\
Correlation coefficient & 0.9998 \\
\hline
\end{tabular}

formulation was not significantly altered and only resulted in a change in the retention time. The values obtained for the theoretical plates and the asymmetry were also satisfactory. The results are demonstrated in Table IV.

TABLE II - Method repeatability and intermediate precision for saxagliptin

\begin{tabular}{lcc}
\hline Intra-day precision & Mean $(\%)$ & RSD $(\%)$ \\
\hline Day 1 $(n=6)$ & 101.98 & 1.49 \\
Day 2 $(n=3)^{a}$ & 99.56 & 1.20 \\
Day 3 $(n=3)$ & 100.84 & 1.35 \\
Inter-day precision $^{b}$ & 100.79 & 1.20 \\
\hline
\end{tabular}

${ }^{a}$ Another analyst; ${ }^{b}$ Mean of three days

TABLE III - Results of accuracy by HPLC method

\begin{tabular}{lcccc}
\hline \multirow{2}{*}{ Level (\%) } & \multicolumn{2}{c}{$\begin{array}{c}\text { Amount of the drug } \\
\left(\boldsymbol{\mu g} . \mathbf{m L}^{-1}\right)\end{array}$} & $\begin{array}{c}\text { Recovery } \\
(\%)\end{array}$ & RSD (\%) \\
\cline { 2 - 3 } & added & found & & \\
\hline \multirow{3}{*}{80} & 15.28 & 15.48 & 101.33 & \\
& 19.80 & 20.08 & 101.42 & 0.38 \\
& 19.50 & 19.63 & 100.70 & \\
\hline \multirow{3}{*}{100} & 25.47 & 25.81 & 101.37 & \\
& 30.27 & 30.33 & 100.95 & 0.32 \\
& 28.51 & 40.25 & 101.59 & \\
\hline \multirow{3}{*}{120} & 35.65 & 35.63 & 99.56 & \\
& 40.16 & 28.96 & 100.24 & 0.43 \\
& 38.28 & 38.05 & 99.42 & \\
\hline
\end{tabular}

TABLE IV - Robustness results of saxagliptin by the developed method

\begin{tabular}{lcccccc}
\hline Parameters & Value & Assay (\%) & \%RSD & RT $^{a}(\mathbf{m i n})$ & $\begin{array}{c}\text { Theoretical } \\
\text { Plates }\end{array}$ & Asymmetry \\
\hline \multirow{3}{*}{ Flow rate (mL.min $\left.{ }^{-1}\right)$} & 0.8 & 99.57 & & 10.06 & 7693 & 1.09 \\
& 1.0 & 99.48 & 0.57 & 8.12 & 7231 & 1.12 \\
& 1.2 & 100.50 & & 7.17 & 6316 & 1.12 \\
\hline \multirow{3}{*}{$0.1 \%$ phosphoric acid } & 2.5 & 98.81 & & 8.24 & 7224 & 1.07 \\
& 3.0 & 98.36 & 0.31 & 8.08 & 6943 & 1.06 \\
& 3.5 & 98.23 & & 8.62 & 7245 & 1.06 \\
\hline \multirow{3}{*}{ Proportion of mobile phase } & $75: 25$ & 98.75 & & 10.20 & 7130 & 1.06 \\
& $70: 30$ & 100.56 & 1.11 & 8.28 & 7205 & 1.10 \\
& $65: 35$ & 100.77 & & 7.83 & 7168 & 1.18 \\
\hline
\end{tabular}

${ }^{a} \mathrm{RT}$ : retention time 


\section{System suitability}

The suitability of the chromatographic system was tested before starting the work to evaluate the asymmetry, number of theoretical plates and capacity factor $\left(k^{\prime}\right)$, with average results of $1.11,7,805$ and 2.25 , respectively. The RSD of the peak area was $1.25 \%$. The experimental results were within the acceptable values, indicating that the system is suitable for the analysis intended.

\section{CONCLUSION}

The developed method was found to be precise with RSD values for intra-day and inter-day precision studies less than $1.49 \%$. Good recoveries for the drug were obtained at each added concentration, indicating that the method was accurate. During robustness check, the RSD and percentage of drug content is well within the acceptance criteria. Specificity was indicated by the resolution of saxagliptin peak from the peaks of degradation product. The peak purity profile by PDA detector confirmed the specificity without any interference from the degradation products. Hence, the proposed RPLC method can be successfully applied during stability studies of saxagliptin in pharmaceutical dosage form.

\section{ACKNOWLEDGMENTS}

The authors acknowledge the financial support provided by the foundations CNPq, CAPES and FAPERGS.

\section{REFERENCES}

AUGERI, D. J.; ROBL, J. A.; BETEBENNER, D. A.; MAGNIN, D. R.; KHANNA, A.; ROBERTSON, J. G.; WANG, A.; SIMPKINS, L. M.; TAUNK, P.; HUANG, Q.; HAN, S.; ABBOA-OFFEI, B.; CAP, M.; XIN, L.; TAO, L.; TOZZO, E.; WELZEL, G. E.; EGAN, D. M.; MARCINKEVICIENE, J.; CHANG, S. Y.; BILLER, S. A.; KIRBY, M. S.; PARKER, R. A.; HAMANN, L. G. Discovery and preclinical profile of Saxagliptin (BMS: 477118): a highly potent, longacting, orally active dipeptidyl peptidase IV inhibitor for the treatment of type 2 diabetes. J. Med. Chem., v.48, n.15, p.5025-5037, 2005 .

DEACON, C. F.; HOLST, J. J. Saxagliptin: a new dipeptidyl peptidase-4 inhibitor for the treatment of type 2 diabetes. Adv. Ther., v.26, n.5, p.488-499, 2009.
EUROPEAN MEDICINES AGENCY. EMEA. CHMP assessment report for Onglyza. London: European Medicines Agency, 2009. Available at: < http://goo.gl/ Jd79Kr $>$. Accessed on: 07 Aug. 2013.

EUROPEAN MEDICINES AGENCY. EMEA. Assessment report for Onglyza. London: European Medicines Agency, 2013. Available at: $<$ http://www.ema.europa.eu/docs/ en_GB/document_library/EPAR_-_Assessment_Report_Variation/human/001039/WC500104371.pdf $>$. Accessed on: 10 Jan. 2014.

GAO, J.;YUAN, Y.; LU, Y.; YAO, M. Development of a rapid UPLC-MS/MS method for quantification of saxagliptin in rat plasma and application to pharmacokinetic study. Biomed. Chromatogr., v.26, p.1482-1487, 2012.

INTERNATIONAL CONFERENCE ON HARMONIZATION. ICH. Guideline Q2-R1: validation of analytical procedures: text and methodology. Geneva, Switzerland: International Conference on Harmonization, 2005. Available at: $<$ http:// goo.gl/kj8Irm>. Accessed on: 06 Aug. 2013.

KALAICHELVI, R.; JAYACHANDRAN, E. Validated spectroscopic method for estimation of saxagliptin in pure and from tablet formulation. Int. J. Pharm. Pharm. Sci., v.3, p.179-180, 2011.

KARYEKAR, C.; DONOVAN, M.; ALLEN, E.; FLEMING, D.; RAVICHANDRAN, S.; CHEN, R. Efficacy and safety of saxagliptin combination therapy in US patients with type 2 diabetes. Postgrad. Med., v.123, n.4, p.63-70, 2011.

PATEL, C. G.; ZHANG, J.; LI, L.; GOODING, L.; CROOP, R.; LI, T.; BOULTON, D. W. Effect of a high-fat meal on the pharmacokinetics of saxagliptin in healthy subjects. J. Clin. Pharmacol., v.50, p.1211-1216, 2010.

XU, X.; DEMERS, R.; GU, H.; CHRISTOPHER, L. J.; SU, H.; COJOCARU, L.; BOULTON, D. W.; KIRBY, M.; STOUFFER, B.; HUMPHREYS, W. G.; ARNOLD, M. E. Liquid Chromatography and tandem mass spectrometry method for the quantitative determination of saxagliptin and its major pharmacologically active 5-monohydroxy metabolite in human plasma: Method validation and overcoming specific and non-specific binding at low concentrations. J. Chromatogr. B, v.889-890, p.77-86, 2012.

Received for publication on $07^{\text {th }}$ July 2014 Accepted for publication on $26^{\text {th }}$ November 2014 